Jana Marie Safrankova,

Associate Professor, College of Regional Development and Banking Institute - AMBIS, Czech Republic

ORCID ID, 0000-0003-1578-0495

email: jana.safrankova@ambis.cz

\title{
Martin Sikyr,
}

College of Regional Development and Banking Institute - AMBIS, Czech Republic

email: martin.sikyr@ambis.cz

\section{Renata Skypalova,}

Ph.D., College of Regional Development and Banking Institute - AMBIS, Czech Republic

email: renata.skypalova@ambis.cz

Correspondence author: jana.safrankova@ambis.cz

\section{INNOVATIONS IN WORKFORCE MANAGEMENT: CHALLENGES IN THE FOURTH INDUSTRIAL REVOLUTION}

Abstract. The radical technological changes in business models associated with the fourth industrial revolution $(4 I R)$ naturally change workforce requirements and approach to workforce management. To deal with the workforce management challenges of the 4IR, employers should know requirements and expectations of the potential workforce to be able to apply effective and efficient strategies, policies, and practices on workforce management to ensure the organization has quality employees it needs. The article aims to present the main findings of the authors' questionnaire survey on requirements and expectations of Czech employees associated with the fourth industrial revolution and discuss the current workforce management challenges in developing attractive career opportunities. The authors' questionnaire survey was carried out from September to December 2019. The respondents included Czech male and female employees of different professions and different generations. The answers were obtained from 168 respondents. The data analysis methods included the calculation of relative frequencies and the evaluation of the dependence of responses on gender and generation of respondents using contingency tables and chi-square tests of independence. The findings show that respondents are familiar with the 4IR, and they are not concerned about losing their jobs due to the development of digitization, automation, or robotization; however, they are aware of the fact that their knowledge, skills, and abilities determine their employability in the 4IR. On the other hand, they have relatively high job expectations, which could reduce their employability. Therefore, employers should learn how to know the requirements and expectations of the potential workforce to be able to develop attractive career opportunities.

Keywords: Czech Republic, employee expectations, employment opportunities, human resource management, industry 4.0, working conditions.

Introduction. The fourth industrial revolution (4IR) is characterized by a progressive and pervasive application of interdependent digital technologies and a rise of smart industrial businesses (Muscio and Ciffolilli, 2020). The application of digital technologies offers new values and services to customers and businesses, but at the same time, it causes significant changes in all industrial sectors and businesses (Paulo et al., 2019).

The implementation of digital technologies in industrial businesses has a far-reaching impact on industrial value creation. However, the practical relevance of digital technologies implies that it is essential to understand the underlying dynamics of their implementation as well as their opportunities and challenges for industrial businesses (Muller and Kiel, 2018). The successful transformation of the 4IR concepts into practice is possible only about the external and internal conditions of specific industrial businesses (Lass and Gronau, 2020).

Cite as: Safrankova, J. M., Sikyr, M., \& Skypalova, R. (2020). Innovations in Workforce Management: Challenges in the Fourth Industrial Revolution. Marketing and Management of Innovations, 2, 85-94. http://doi.org/10.21272/mmi.2020.2-06 

Revolution

From the perspective of the Czech Republic, as a traditional industrial country, the implementation of digital technologies in industrial businesses associated with the fourth industrial revolution is a great opportunity and a challenge. In the Czech Republic, examples of the implementation of the 4IR concepts are observed in many industries; however, the implementation of digital technologies is the fastest in the automotive, electrotechnical, pharmaceutical, or chemical-technological industry (Adamek, 2018). However, the fourth industrial revolution also brings some problems in the labor market, especially a severe shortage of quality employees (Kostalova and Bednaríkova, 2019). Today's job applicants must demonstrate solid professional and personal knowledge, skills, and abilities for successful performance in the organization. However, there is a shortage of such job applicants in today's Czech labor market. Although many job applicants do not meet the job requirements, their job and career expectations are relatively high (Safrankova and Sikyr, 2017).

The article aims to present the main findings of the authors' questionnaire survey on requirements and expectations of Czech employees associated with the development of the fourth industrial revolution and discuss the current workforce management challenges in developing attractive career opportunities.

The article includes four parts. The first part - literature review - summarizes the findings of earlier studies on the concept of the fourth industrial revolution and the impact of the fourth industrial revolution on the workforce. The second part - methodology and research methods - describes methods of the authors' questionnaire survey on requirements and expectations of Czech employees associated with the development of the fourth industrial revolution. The third part - results - presents and discusses the main findings of the authors' questionnaire survey focused on the requirements and expectations of Czech employees associated with the development of the fourth industrial revolution. The fourth part conclusions - summarizes the article, includes implications for practice, and defines research limitations and suggestions for future research.

Literature Review. The fourth industrial revolution (4IR) is the environment in which progressive digital technologies are radically affecting and changing the way people live and work (Dean and Spoehr, 2018). The $4 I R$ is based on the digitalization of business processes and activities (Pekerşen \& Tugay, 2020; Sotnyk et al., 2020), gathering and analyzing data across machines and transformation of businesses into smart and sustainable ones (Habanik et al., 2019). Through digitalization, the business processes and activities are getting evolved, and accurate results are being produced, which in turn helps to increase productivity (Sanghavi et al., 2019). However, digital technologies are not only a tool for increasing the productivity of the economy but also a driver of the technological development of the economy (Gera and Singh, 2019).

The application of digital technologies drives changes in traditional business models when linear value chains are destroyed and replaced by value networks. This happens because customers become part of the value chain, which changes traditional relationships among producers, traders, and customers (Botha, 2019). It is also expected that the $4 I R$ will be capable of functioning as a new alternative to enhance the quality of the environment. The environmental industry and environmental technologies may be vital economic factors in next-generation society (Choi et al., 2019). On the other hand, 4IR forces people to rethink their approaches to work and life. In these processes, education plays a unique role because it promises to prepare the coming generations for the challenges ahead and transform society for the better (Scepanovic, 2019).

The revolutionary technological advancement associated with the 4IR naturally affects all industries and businesses (Postelnicu and Calea, 2019), and this revolution brings along significant changes in labor markets (Habanik et al., 2019). The introduction of digital technologies in industrial businesses is evoking profound changes in their work systems (Fedulova et al., 2018). It is estimated that the emerging changes will affect both the overall performance of work systems and the well-being of people working in and interacting with the work systems (Kadir and Broberg, 2020). Increasing automation and computerization 

Revolution

lead to changes in human work (Becker and Stern, 2016).

The future industrial businesses will provide less easy and repetitive but more advanced and complex tasks (Becker and Stern, 2016). The application of digital technologies encourages decentralization and increases the interaction between humans and machines (Barata et al., 2019). Also, many jobs are rapidly disappearing because their tasks are automated, which applies both to low-skilled manual and routine jobs and increasingly to medium-skilled specialized jobs and even high-skilled complex jobs (Marengo, 2019). From the perspective of workforce management challenges in the fourth industrial revolution, the competition in recruiting and retaining talented people together with the uncertainty of employees about what they will face and obtain in the course of working for employers are two significant problems. Employers should make their employees satisfied and pleased with their career opportunities. This satisfaction and pleasure are hoped to be critical factors in motivating employees to perform their jobs and meet the objectives of the business (Nangoy et al., 2020).

The competition in recruiting and retaining talented people generally arises from a severe shortage of quality employees on the labor market (Kostalova and Bednaríkova, 2019). The shortage of skilled people willing to work in industrial businesses supports, but at the same time limits the introduction of digital technologies in industrial companies (Pardi, 2019). Improving this state would require changes in the education system and the cooperation between employers and educational institutions (Safrankova and Sikýr, 2017). The uncertainty about career opportunities generally arises from potential occupational health and safety problems. The 4IR brings nonstandard career opportunities. The increasing application of digital technologies can lead to new forms of diseases and accidents (Min et al., 2019).

Methodology and research methods. Achieving the aim of the article is based on the analysis of earlier studies on the workforce management practice and the results of the authors' questionnaire survey on requirements and expectations of Czech employees associated with the development of the fourth industrial revolution. The survey was carried out by authors (Jana Marie Safrankova, Martin Sikýr, and Renata Skýpalova) from September to December 2019. The questionnaire applied included 18 multiplechoice questions focused on employee requirements and expectations associated with the fourth industrial revolution. The respondents included Czech male and female employees of different professions and different generations. The answers were obtained from 168 respondents. The respondents were characterized by gender (32\% male, 68\% female) and generation (37\% generation $X: 1965-1980,25 \%$ generation Y: 1981-1994, and 38\% generation Z: 1995-2010). The data analysis methods included both the calculation of relative frequencies (as a share from the total number of respondents) and the evaluation of the dependence of responses on gender (male and female respondents) and generation (respondents of generation X: 1965-1980, respondents of generation Y: 1981-1994, and respondents of generation Z: 1995-2010). The evaluation was conducted by developing contingency tables and performing chi-square tests of independence.

By the aim of the survey, six hypotheses concerning the requirements and expectations of respondents associated with the development of the fourth industrial revolution were tested. The hypotheses tested were as follows: 1) there is no difference in responses depending on the gender of respondents regarding the concern about losing their jobs due to the development of digitization, automation or robotization; 2 ) there is no difference in responses depending on the gender of respondents regarding more chances to meet the challenges of the 4IR as a result of higher education; 3 ) there is no difference in responses depending on the gender of respondents regarding the desire to be a manager; 4) there is no difference in responses depending on the generation of respondents regarding the desire to work in the place of residence; 5) there is no difference in responses depending on the generation of respondents regarding the acceptable gross monthly income, and 6) there is no difference in responses depending on the generation of respondents regarding the motivation to change a job because of the offer of benefits. 
The procedure of the chi-square tests of independence included six steps:

1) formulation of the null $\left(H_{0}\right)$ and alternative $\left(H_{A}\right)$ hypothesis;

2) selection of a level of significance $a$;

3) calculation of the chi-square statistic

$$
\mathrm{X}^{2}=\sum\left[\frac{\left(o_{r, c}-E_{r, c}\right)^{2}}{E_{r, c}}\right]
$$

where $O$ is observed frequencies, $E$ is expected rates, $r$ is the number of rows in the contingency table, and $\mathrm{c}$ is the number of columns in the contingency table;

4) calculation of the degrees of freedom

5) selection of the critical chi-square value $X^{2} a(f)$;

$$
\mathrm{f}=(r-1) \times(c-1) ; 5)
$$

6) comparison of the chi-square statistic $X^{2}$ to the critical chi-square value $X^{2} a(f)$ and acceptation or rejection of the null hypothesis.

Results. In the case of general awareness of the concept of the fourth industrial revolution (4IR), 89\% of respondents agreed that they know the idea. In this context, respondents stated that this concept is mainly characterized by automation of production $(82 \%)$, robotics $(74 \%)$, or application of new technologies $(68 \%)$. When it comes to the question of whether respondents are concerned about losing their jobs due to the development of digitization, automation, or robotization, $6 \%$ of them stated yes, $80 \%$ of them reported no, and $14 \%$ of them reported don't know. There was no significant difference in responses depending on the gender of respondents $(p>0.05)$. The null hypothesis was tested that there is no difference in responses depending on the gender of respondents regarding the concern about losing their jobs due to the development of digitization, automation, or robotization (see Table 1). Since the test statistics were lower than the critical value, the null hypothesis was not rejected.

Table 1. Are you concerned about losing your job due to the development of digitization, automation, or robotization?

\begin{tabular}{lcccc}
\hline Gender & Yes & No & Don't know & $\sum$ \\
\hline Male respondents & $2^{*}(3.21)^{\star *}$ & $48(43.07)$ & $4(7.71)$ & $\mathbf{5 4}$ \\
Female respondents & $8(6.79)$ & $86(90.93)$ & $20(16.29)$ & 114 \\
$\Sigma$ & 10 & 134 & $\mathbf{2 4}$ & 168 \\
\hline
\end{tabular}

*observed frequencies $(0),{ }^{* *}$ expected frequencies $(\mathrm{E})$

$\mathrm{H}_{0}$ : There is no difference in responses depending on the gender of respondents regarding the concern about losing their jobs due to the development of digitization, automation, or robotization. $\mathrm{H}_{\mathrm{A}}$ : There is a difference in responses depending on the gender of respondents regarding the concern about losing their jobs due to the development of digitization, automation, or robotization.

Level of significance $\alpha=0.05$; Chi square statistic $\chi^{2}=\sum\left[\frac{\left(o_{r, c}-E_{r, c}\right)^{2}}{E_{r, c}}\right]=4.143$

Degrees of freedom $(\mathrm{f}):(r-1) \times(c-1)=2$; Critical chi-square value $\chi^{2} 0,05(2)=5.991$

$r-$ the number of rows in the contingency table, $c-$ the number of columns in the contingency table

Sources: developed by the authors.

When it comes to the question of whether respondents can imagine that machines or robots could replace some people in their organization, $45 \%$ of them stated yes, $42 \%$ of them reported no, and $13 \%$ of them reported don't know.

When it comes to the question to what extent information and communication technologies influence daily work activities of respondents, $52 \%$ of them stated maximum, $36 \%$ of them stated average, and $12 \%$ of them indicated minimum. Similarly, when it comes to the question to what extent computer work is part of daily work activities of respondents, $76 \%$ of them stated maximum, $17 \%$ of them stated average, and 

Revolution

$7 \%$ of them indicated minimum. In the context of computer work, respondents indicated that usually use a word processor $(99 \%)$, a spreadsheet $(93 \%)$, an email client $(81 \%)$, or a presentation maker $(76 \%)$.

When it comes to the question of whether the employer of respondents invests in digitization, automation, or robotization, $47 \%$ of them stated yes, $39 \%$ of them said no, and $14 \%$ of them stated don't know. Similarly, when it comes to the question of whether the employer of respondents invests in their education in connection with the application of information and communication technologies, $40 \%$ of them said yes, $42 \%$ of them said no, and $18 \%$ of them said they don't know.

The results of the authors' questionnaire survey showed that information and communication technologies are a standard part of workplaces and that respondents usually use them to carry out their daily work activities. However, to meet the challenges of digitization, automation, or robotization, they need to develop their professional skills continually. According to respondents, the most critical skills necessary for meeting the challenges of the $4 \mathrm{IR}$ include communication skills (84\%), solving-problems skills (84\%), implementation skills $(76 \%)$, learning skills $(68 \%)$, or teamwork skills $(61 \%)$. On the other hand, respondents showed relatively high job expectations. The respondents' job expectations include selffulfillment (87\%), meaningful work (78\%), professional development (68\%), favorable environment (68\%), fair wages $(67 \%)$, friendly team $(65 \%)$, or professional management $(61 \%)$.

In the context of employability, $82 \%$ of respondents agreed that higher education gives them more chances to meet the challenges of the 4IR. There was a significant difference in responses depending on the gender of respondents $(p<0.05)$. The null hypothesis was tested that there is no difference in answers depending on the gender of respondents regarding more chances to meet the challenges of the 4IR as a result of higher education (see Table 2). Since the test statistics were higher than the critical value, the null hypothesis was rejected in favor of the alternative hypothesis. However, $52 \%$ of respondents stated that they see their chances in today's labor market as a medium. This may be due to uncertainty regarding career opportunities.

Table 2. Do you think that higher education gives you more chances to meet the challenges of the 4IR?

\begin{tabular}{lccc}
\hline Gender & Yes & No & $\sum$ \\
\hline Male respondents & $36^{*}(14.24)^{* *}$ & $18(13.76)$ & 54 \\
Female respondents & $102(34.08)$ & $12(32.92)$ & 114 \\
$\Sigma$ & 138 & 30 & 168 \\
\hline
\end{tabular}

${ }^{*}$ observed frequencies $(0),{ }^{* *}$ expected frequencies $(\mathrm{E})$

$\mathrm{H}_{0}$ : There is no difference in responses depending on the gender of respondents regarding more chances to meet the challenges of the $4 I R$ as a result of higher education. $H_{A}$ : There is a difference in responses depending on the gender of respondents regarding more chances to meet the challenges of the $4 \mathrm{IR}$ as a result of higher education.

Level of significance $\alpha=0.05$; Chi square statistic $\chi^{2}=\sum\left[\frac{\left(o_{r, c}-E_{r, c}\right)^{2}}{E_{r, c}}\right]=12.994$

Degrees of freedom (f): $(r-1) \times(c-1)=1$; Critical chi-square value $\chi^{2} 0,05(1)=3.841$

$r$ - the number of rows in the contingency table, $c$ - the number of columns in the contingency table

Source: developed by the authors.

When it comes to the question of whether respondents want to be managers (manage people), $69 \%$ of them stated yes, $7 \%$ of them said no, and $24 \%$ of them stated don't know yet. There was no significant difference in responses depending on the gender of respondents $(p>0.05)$. The null hypothesis was tested that there is no difference in answers depending on the gender of respondents regarding the desire 
J. M., Safrankova, M., Sikyr, R., Skypalova. Innovations in Workforce Management: Challenges in the Fourth Industrial Revolution

to be a manager (see Table 3). Since the test statistics were lower than the critical value, the null hypothesis was not rejected.

Table 3. Do you want to be a manager?

\begin{tabular}{lcccc}
\hline Gender & Yes & No & Don't know yet & $\sum$ \\
\hline Male respondents & $42^{*}(37.29)^{\star *}$ & $4(3.86)$ & $8(12.86)$ & 54 \\
Female respondents & $74(78.71)$ & $8(8.14)$ & $32(27.14)$ & 114 \\
$\Sigma$ & 116 & 12 & 40 & 168 \\
\hline
\end{tabular}

*observed frequencies (0), ${ }^{* *}$ expected frequencies $(\mathrm{E})$

$\mathrm{H}_{0}$ : There is no difference in responses depending on the gender of respondents regarding the desire to be a manager. $\mathrm{H}_{\mathrm{A}}$ : There is a difference in responses depending on the gender of respondents regarding the desire to be a manager.

Level of significance $\alpha=0.05$; Chi square statistic $X^{2}=\sum\left[\frac{\left(o_{r, c}-E_{r, c}\right)^{2}}{E_{r, c}}\right]=3.590$

Degrees of freedom (f): $(r-1) \times(c-1)=2$; Critical chi-square value $\chi^{2} 0,05(2)=5.991$

$r-$ the number of rows in the contingency table, $c-$ the number of columns in the contingency table

Source: developed by the authors.

An interesting problem associated with working conditions is the need to commute to work. When it comes to the question of whether respondents want to work at their place of residence, $51 \%$ of them stated yes, $19 \%$ of them said no, and $30 \%$ of them stated don't know yet. There was a significant difference in responses depending on the generation of respondents $(p<0.05)$. The null hypothesis was tested that there is no difference in answers depending on the production of respondents regarding the desire to work in the place of residence (see Table 4). Since the test statistics were higher than the critical value, the null hypothesis was rejected in favor of the alternative hypothesis.

Table 4. Do you want to work at your place of residence?

\begin{tabular}{lcccc}
\hline Generation & Yes & No & Don't know yet & $\Sigma$ \\
\hline X: 1965-1980 & $42^{*}(31.74)^{* *}$ & $10(11.81)$ & $10(18.45)$ & 62 \\
Y: 1981-1994 & $28(21.50)$ & $6(8.00)$ & $8(12.50)$ & 42 \\
$Z: 1995-2010$ & $16(32.76)$ & $16(12.19)$ & $32(19.05)$ & 64 \\
$\Sigma$ & 86 & 32 & 50 & 168 \\
\hline
\end{tabular}

${ }^{*}$ observed frequencies $(\mathrm{O}),{ }^{* *}$ expected frequencies $(\mathrm{E})$

$\mathrm{H}_{0}$ : There is no difference in responses depending on the generation of respondents regarding the desire to work in the place of residence. $\mathrm{H}_{\mathrm{A}}$ : There is a difference in responses depending on the generation of respondents regarding the desire to work in the area of the house.

Level of significance $\alpha=0.05$; Chi square statistic $X^{2}=\sum\left[\frac{\left(o_{r, c}-E_{r, c}\right)^{2}}{E_{r, c}}\right]=30.126$

Degrees of freedom $(f):(r-1) \times(c-1)=4$; Critical chi-square value $X^{2} 0,05(4)=9.488$

$r$ - the number of rows in the contingency table, $c$ - the number of columns in the contingency table

Source: developed by the authors.

When it comes to the question of what gross monthly income respondents consider acceptable, $59 \%$ of them stated EUR 1,550 and more, $27 \%$ of them said EUR 1,150-1,500, and $14 \%$ of them told EUR 750 1,100. In Q3 2019, the average gross monthly nominal wage was approximately EUR 1,300 (CZSO, 2019). 

Revolution

There was no significant difference in responses depending on the gender of respondents $(p>0.05)$, but there was a significant difference in answers depending on the generation of respondents $(p<0.05)$. The null hypothesis was tested that there is no difference in responses depending on the generation of respondents regarding the acceptable gross monthly income (see Table 5). Since the test statistics were higher than the critical value, the null hypothesis was rejected in favor of the alternative hypothesis.

Table 5. What gross monthly income do you consider acceptable?

\begin{tabular}{lcccc}
\hline Generation & EUR 750-1,100 & EUR 1,150-1,500 & EUR 1,550 and more & $\Sigma$ \\
\hline X: 1965-1980 & $4^{*}(8.86)^{* *}$ & $10(16.98)$ & $48(36.17)$ & 62 \\
Y: 1981-1994 & $4(6.00)$ & $12(11.50)$ & $26(24.50)$ & 42 \\
Z: $1995-2010$ & $16(9.14)$ & $24(17.52)$ & $24(37.33)$ & 64 \\
$\Sigma$ & 24 & 46 & 98 & 168 \\
\hline
\end{tabular}

${ }^{*}$ observed frequencies $(\mathrm{O}),{ }^{* *}$ expected frequencies $(\mathrm{E})$

$\mathrm{H}_{0}$ : There is no difference in responses depending on the generation of respondents regarding the acceptable gross monthly income. $\mathrm{H}_{\mathrm{A}}$ : There is a difference in responses depending on the generation of respondents regarding adequate gross monthly income.

Level of significance $a=0.05$; Chi square statistic $\chi^{2}=\sum\left[\frac{\left(o_{r, c}-E_{r, c}\right)^{2}}{E_{r, c}}\right]=22.481$

Degrees of freedom (f): $(r-1) \times(c-1)=4$; Critical chi-square value $\chi^{2} 0,05(4)=9.488$

$r$ - the number of rows in the contingency table, $c$ - the number of columns in the contingency table

Source: developed by the authors.

Besides fair wages, employees and job seekers often expect attractive benefits. When it comes to the question of what benefits respondents expect and consider to be motivating, they stated sick-days (77\%), other vacations $(72 \%)$, pension/life insurance contributions $(61 \%)$, education contributions $(60 \%)$, or meal vouchers $(52 \%)$.

Table 6. Would you change a job because of the offer of benefits?

\begin{tabular}{lccc}
\hline Generation & Yes & No & $\Sigma$ \\
\hline X: 1965-1980 & $42^{*}(51.67)^{\star *}$ & $20(10.33)$ & 62 \\
Y: 1981-1994 & $38(35.00)$ & $4(7.00)$ & 42 \\
$Z: 1995-2010$ & $60(53.33)$ & $4(10.67)$ & 64 \\
$\Sigma$ & 140 & 28 & 168 \\
\hline
\end{tabular}

*observed frequencies (O), ${ }^{* *}$ expected frequencies $(\mathrm{E})$

$\mathrm{H}_{0}$ : There is no difference in responses depending on the generation of respondents regarding the motivation to change a job because of the offer of benefits. $\mathrm{H}_{\mathrm{A}}$ : There is a difference in responses depending on the generation of respondents regarding the motivation to change a job because of the offer of benefits.

Level of significance $\alpha=0.05$; Chi square statistic $\chi^{2}=\sum\left[\frac{\left(o_{r, c}-E_{r, c}\right)^{2}}{E_{r, c}}\right]=17.394$

Degrees of freedom (f): $(r-1) \times(c-1)=2$; Critical chi-square value $X^{2} 0,05(2)=5.991$

$r$ - the number of rows in the contingency table, $c$ - the number of columns in the contingency table

Source: developed by the authors.

When it comes to the question of whether the offer of benefits could motivate respondents to change their jobs, $83 \%$ of them stated yes, and only $17 \%$ of them said no. There was no significant difference in responses depending on the gender of respondents $(p>0.05)$, but there was a significant difference in 
responses depending on the generation of respondents $(p<0.05)$. The null hypothesis was tested that there is no difference in answers depending on the generation of respondents regarding the motivation to change a job because of the offer of benefits (see Table 6). Since the test statistics were higher than the critical value, the null hypothesis was rejected in favor of the alternative hypothesis.

Conclusions. The authors' questionnaire survey on requirements and expectations of Czech employees associated with the fourth industrial revolution (4IR) showed that male and female respondents of different professions and different generations are familiar with the 4IR concept and that information and communication technologies are a standard part of their workplaces. In contrast, respondents frequently use them to carry out their daily work activities.

Respondents are not concerned about losing their jobs due to the development of digitization, automation, or robotization. However, they are aware of the fact that their knowledge, skills, and abilities determine their employability in the 4IR. On the other hand, respondents have relatively high job expectations, including self-fulfillment, meaningful work, professional development, favorable environment, fair wages, attractive benefits, friendly team, or professional management. Failure to meet all these expectations could lead to dissatisfaction and limited employability of respondents. Respondents, respectively, employees and job seekers in general, should be ready to continually develop their professional skills to meet the challenges of the 4IR.

The results support the suggestion that employers should learn how to know the requirements and expectations of the potential workforce to be able to develop attractive career opportunities. Employers should improve their understanding of specific needs and expectations of employees and job seekers and develop attractive career opportunities for them to motivate them to perform their jobs and meet objectives of the business successfully.

The focus on the Czech labor market and the relatively low number of respondents limit general conclusions. However, the current results are worth attention from business managers and HR specialists who are responsible for workforce management in different organizations. The present results can be the starting point for further research on workforce management in the 4IR.

Author Contributions: Conceptualization, J. M. S., M. S., and R. S.; methodology, J. M. S., M. S., and R. S.; formal analysis, J. M. S., M. S., and R. S.; investigation, M. S. and R. S.; resources, J. M. S., M. S., and R. S.; writing一original draft preparation, M. S.

Funding: This research was funded by the Internal Grant Agency of College of Regional Development and Banking Institute - AMBIS, grant number VP-PR-29.

\section{References}

Adamek, P. (2018). A Research Agenda of Industry 4.0 from the Czech Perspective. In Digital Transformation in Smart Manufacturing. InTechOpen. [Google Scholar] [CrossRef]

Barata, J., Cunha, P. R., \& Coyle, S. (2019). Evolving manufacturing mobility in Industry 4.0: the case of process industries. Journal of Manufacturing Technology Management, 31(1), 52-71. [Google Scholar] [CrossRef]

Becker, T., \& Stern, H. (2016). Future trends in human work area design for cyber-physical production systems. Procedia Cirp, 57, 404-409. [Google Scholar] [CrossRef]

Botha, A. P. (2019). Innovating for market adoption in the fourth industrial revolution. South African Journal of Industrial Engineering, 30(3), 187-198. [Google Scholar] [CrossRef]

Choi, C., Kim, C., \& Kim, C. (2019). Towards sustainable environmental policy and management in the fourth industrial revolution: Evidence from big data analytics. Journal of Asian Finance, Economics and Business, 6(3), 185-192. [Google Scholar] [CrossRef]

CZSO (2019). Average wages - Q3 2019. The Czech Statistical Office. Retrieved May 10, 2020, from https://www.czso.cz/csu/czso/cri/prumerne-mzdy-3-ctvrtleti-2019

Dean, M., \& Spoehr, J. (2018). The fourth industrial revolution and the future of manufacturing work in Australia: challenges and opportunities. Labour \& Industry: a journal of the social and economic relations of work, 28(3), 166-181. [Google Scholar] [CrossRef]

Fedulova, I., Piatnytska, G., \& Lukashova, L. (2018). Small business in Ukraine: peculiarities and problems of development in the conditions of the fourth industrial revolution. Marketing and Management Innovations, 3, 216-228. [Google Scholar] [CrossRef] 


\section{J. M., Safrankova, M., Sikyr, R., Skypalova. Innovations in Workforce Management: Challenges in the Fourth Industrial}

Revolution

Gera, I., \& Singh, S. (2019). A critique of economic literature on technology and fourth industrial revolution: employment and the nature of jobs. Indian Journal of Labour Economics, 62(4), 715-729. [Google Scholar] [CrossRef]

Habanik, J., Grencikova, A., \& Krajco, K. (2019). The impact of new technology on sustainable development. Engineering Economics, 30(1), 41-49. [Google Scholar] [CrossRef]

Kadir, B. A., \& Broberg, O. (2020). Human well-being and system performance in the transition to industry 4.0. International Journal of Industrial Ergonomics, 76. [Google Scholar] [CrossRef]

Kostalova, J., \& Bednaríkova, M. (2019). An analysis of the chemical industry labour market in the Czech Republic. Chemicke Listy, $\quad 113(11), \quad 691-696 . \quad$ Retrieved $\quad$ from https://www.researchgate.net/publication/339473363 An Analysis of the Chemical_Industry Labour_Market in the Czech Rep ublic

Lass, S., \& Gronau, N. (2020). A factory operating system for extending existing factories to Industry 4.0. Computers in Industry. 115. [Google Scholar] [CrossRef]

Marengo, L. (2019). Is this time different? A note on automation and labour in the fourth industrial revolution. Journal of Industrial and Business Economics, 46(3), 323-331. [Google Scholar] [CrossRef]

Min, J., Kim, Y., Lee, S., Jang, T. W., Kim, I., \& Song, J. (2019). The fourth industrial revolution and its impact on occupational health and safety, worker's compensation and labor conditions. Safety and Health at Work, 10(4), 400-408. [Google Scholar] [CrossRef]

Muller, J. M., Kiel, D., \& Voig, K. I. (2018). What drives the implementation of industry 4.0? The role of opportunities and challenges in the context of sustainability. Sustainability, 10(1), 247. [Google Scholar] [CrossRef]

Muscio, A., \& Ciffolilli, A. (2020). What drives the capacity to integrate Industry 4.0 technologies? Evidence from European R\&D projects. Economics of Innovation and New Technology, 29(2), 169-183. [Google Scholar] [CrossRef]

Nangoy, R., Mursitama, T., Setiadi, N., \& Pradipto, Y. (2020). Creating sustainable performance in the fourth industrial revolution era: The effect of employee's work well-being on job performance. Management Science Letters, 10(5), 1037-1042. [Google Scholar] [CrossRef]

Pacchini, A. P. T., Lucato, W. C., Facchini, F., \& Mummolo, G. (2019). The degree of readiness for the implementation of Industry 4.0. Computers in Industry. 113. [Google Scholar] [CrossRef]

Pardi, T. (2019). Fourth industrial revolution concepts in the automotive sector: performativity, work and employment. Journal of Industrial and Business Economics, 46(3), 379-389. [Google Scholar] [CrossRef]

Pekerşen, Y., Tugay, O (2020). Professional Satisfaction as a Key Factor in Employee Retention: A case of the Service Sector. Journal of Tourism and Services, 20(11), 1-27. [CrossRef]

Postelnicu, C., \& Calea, S. (2019). The fourth industrial revolution. Global risks, local challenges for employment. Montenegrin Journal of Economics, 15(2), 195-206. [Google Scholar]

Safrankova, J.M., \& Sikýr, M. (2017). Prospects of Human Capacity Development: Challenges of Current Human Resource Management Practice. Ostrava: KEY Publishing.

Sanghav, D., Parik, S., \& Raj, S. A. (2019). Industry 4.0: tools and implementation. Management and Production Engineering Review, 10(3), 3-13. [Google Scholar] [CrossRef]

Scepanovic, S. (2019). The fourth industrial revolution and education. In 2019 8th Mediterranean Conference on Embedded Computing, MECO 2019 - Proceedings. Institute of Electrical and Electronics Engineers Inc. [CrossRef]

Sotnyk, I. M, Zavrazhnyi, K. Y., Kasianenko, V. O., Roubik, H., \& Sidorov, O. (2020). Investment management of business digital innovations. Marketing and Management of Innovations, 1, 95-109. [Google Scholar] [CrossRef]

Яна Марі Сафранкова, Ph.D., доцент, Вища школа регіонального розвитку та Банківський інститут - AMБІC, Чеська Республіка

Мартін Шікерж, Ph.D., доцент, Вища школа регіонального розвитку та Банківський інститут - АМБІC, Чеська

Республіка

Рената Скипалова, Ph.D., доцент, Вища школа регіонального розвитку та Банківський інститут - AMБIC, Чеська

Республіка

Інноваційні підходи до управління персоналом: вплив четвертої промислової революції

Ця стаття узагальнює аргументи та контраргументи в межах наукової дискусії з питання особливостей інноваційного процесу та нововведень управління персоналом, проблем розробки та впровадження інноваційних технологій в управління персоналом. Систематизаиія літературних джерел та підходів до вирішення проблеми управління персоналом засвідчила, що трудова діяльність сучасного працівника внаслідок дії четвертої промислової революції набуває все більш ярко вираженої специськи, яку необхідно враховувати при впровадженні в практику кадрових інновацій у відповідності з поточними і стратегічними иілями підприємств. Актуальність вирішення даної науковоі проблеми продиктовано необхідністю вдосконалення стратегії, принципів та практики управління персоналом в умовах четвертої промислової революції. Основною метою проведеного дослідження $є$ встановлення специфріки трудової 
J. M., Safrankova, M., Sikyr, R., Skypalova. Innovations in Workforce Management: Challenges in the Fourth Industrial Revolution

діяльності чеських працівників, їх вимоги та очікування спричинених четвертою промисловою революцією. У статті представлено результати емпіричного аналізу опитування 168 респондентів, чоловіки та жінки різних вікових та професійних груп, з вересня по грудень 2019 року. Методичним інструментарієм проведеного дослідження стали методи відносних частот та оцінки залежності відповідей респондентів на основі факторних таблиць та критерію незалежності хі-квадрат. Отримані результати дослідження свідчать, що процеси діджиталізації, автоматизації та роботизації не мають статистично значимого впливу на переживання працівників з приводу можливого ризику втрати робочого місия. Однак, переважна більшість респондентів усвідомлюють, що четверта промислова революція висуває нові вимоги до рівня знань, вмінь та навичок, необхідних для працевлаштування. Дослідження емпірично підтверджує та теоретично доводить, що розуміння працівників майбутніх викликів пов'язаних з впливом четвертої промислової революиії дозволяють впроваджувати на підприємствах сучасні стратегій управління персоналом. Результати проведеного дослідження можуть бути корисними для підприємств при впровадженні інноваційних підходів щодо управління персоналом, зокрема: пошуку та найму працівників, розвитку їх кар'єри, створення корпоративної культури тощо.

Ключові слова: Чеська Республіка, очікування працівників, можливості працевлаштування, управління трудовими ресурсами, індустрія 4.0, робоче середовище.

Manuscript received: 15.01.2020

(C) The author(s) 2020. This article is published with open access at Sumy State University. 